\title{
TEMAS CONTEMPORÂNEOS: O IMPACTO ÉTICO E SOCIAL DA PESQUISA EM GENÉTICA
}

\section{The ethical and social impact in genetics research}

\author{
Mário Antonio Sanches ${ }^{1}$ \\ Gabriela Dias Feitosa ${ }^{2}$
}

\section{Resumo}

A pesquisa genética conheceu novo dinamismo com e após o Projeto Genoma Humano. Na perspectiva da Bioética, esta novidade é acolhida num misto de entusiasmo, realismo e cautela. Entusiasmo, pois toda busca de cura de doenças dos seres humanos e todos os seres vivos têm, inerentemente, justificativa ética. Realismo, pois o novo conhecimento genético se situa, como todo outro conhecimento, numa sociedade já dividida e injustamente desigual. Cautela, pois a força da genética pode acirrar a desigualdade e criar condições tais onde o sonho de uma sociedade democrática pode se transformar numa utopia ainda mais inatingível. Desse modo, se reflete sobre a relação entre genética e justiça social, sobre o modelo de dominação cultural embutido no desenvolvimento tecnológico, sobre os riscos da tentativa de buscar uma superioridade eugênica e sobre a influência do mercado na própria pesquisa genética.

Palavras-chave: Bioética; Genética; Desigualdade social.

\section{Abstract}

The genetic research came to a new dynamism with and after de Human Genome Project. Bioethics received this new knowledge with a mix of enthusiasm, realism and precaution. With enthusiasm because all search for cure of sickness is, by itself, ethically justified. With realism because the new genetic knowledge is situated, as any other knowledge, in a divided and unjustly unequal society. With precaution because the power of genetic can strength inequality and transform our search for a democratic society a utopia even more intangible. Therefore, this work reflects about the relation between genetics and social injustice; about the model of cultural domination that comes together with de technological development; about the risk of trying a eugenic superiority and about the influence of market over the genetic research by itself.

Keywords: Bioethic; Genetics; Social inequality.

1 Doutor em Teologia, EST/IEPG, São Leopoldo, RS, Mestre em Antropologia Social, UFPR, Especialista em Bioética, Diretor do Curso de Teologia da PUCPR (Câmpus Curitiba) e Coordenador do Núcleo de Bioética da PUCPR. M.sanches@pucpr.br

2 Gabriela Dias Feitosa possui Bacharelado e Licenciatura em Biologia pela PUCPR, Especialização em Medicina Nuclear, Especialização em Bioética. Foi membro do Comitê de Ética em Pesquisa dos Hospitais da Aliança Saúde PUCPR - Santa Casa. É integrante da estrutura administrativa da Faculdade Opet. 


\section{Introdução}

O Projeto Genoma Humano, o maior projeto de pesquisa realizado no campo da biologia, construiu mapas genéticos referentes ao genoma humano, realizando o seqüenciamento do DNA humano (PESSINI; BARCHIFONTAINE, 1996; INTERNATIONAL HUMAN GENOME SEQUENCING CONSORTIUM, 2001; VENTER et al, 2001).

Esse projeto e todo o desenvolvimento da pesquisa em genética têm sua justificativa ética enquanto é um esforço para o estudo e a cura de doenças que afetam humanos e os outros animais, mas ao mesmo tempo, esse novo conhecimento e tecnologia se tornam problemáticos, pois podem ser utilizados para outros fins, ou podem trazer consigo um projeto de sociedade estranho aos nossos propósitos.

Vivemos num mundo já dividido entre nações pobres e ricas, entre classes extremamente abastadas e outras extremamente miseráveis, e neste contexto de divisão, o conhecimento e a manipulação do genoma humano pode se tornar uma arma a mais para perpetuar divisões e desigualdades, ou um meio útil para diminuir as diferenças. Quando se faz avaliação ética da genética, no contexto da bioética, traz-se para o debate a problemática da eugenia, da medicina preditiva e do necessário respeito à dignidade humana.

A eugenia tem a pretensão de ser uma ciência que melhora as qualidades inatas da raça e as desenvolve ao máximo, acreditando que os traços favoráveis são sempre inatos (BUCHANAN; BROCK; DANIELS, 2000; MARKS, 1995). Assim, a eugenia manipulava o conceito de raça e projetava uma perspectiva determinista e fechada para as gerações vindouras. Após a Segunda Guerra Mundial, a eugenia foi questionada e condenada internacionalmente, mas infelizmente isso não é tudo, não basta condenar o passado, é necessário cuidar e ter certeza que nós não o repitamos (MARKS, 1995).

Pelo fato da genética ser a ciência da hereditariedade, que promete oferecer grandes benefícios para a humanidade, "é inevitável que a genética de hoje ocorra nas sombras da eugenia", de modo que a eugenia continua sendo apresentada por vários autores como o grande problema ético colocado pelas pesquisas em biotecnologia (BUCHANAN, 1928; SLOAN, 2000). Em vários momentos se percebe que a eugenia deixa de ser coisa do passado, mas se torna ainda uma realidade atual, como afirma Dyck (1997) “a eugenia é praticada hoje".

Um outro aspecto do debate na área das pesquisas em genética é: até que ponto é ético diagnosticar e revelar doenças para as quais ainda não há tratamento, pois a medicina cresce na "capacidade de fazer predições, quanto à possibilidade de que o paciente venha a desenvolver alguma doença (nível fenotípico), com bases em testes laboratoriais em DNA (nível genotípico)" (PENA; AZEVEDO, 1998). Junges (1999) afirma que a medicina preditiva, com sua oportuna terapia, substituirá gradativamente a atual medicina curativa de uma doença já manifesta. Prevê-se que o impacto da chamada medicina genômica será enorme.

Aliado a isso, Mieth (2003) denuncia uma certa "ditadura dos genes". Enquanto que Juengst (2000) afirma existir um certo "imperialismo genético, quando se diz que todas as doenças são realmente genéticas". Juengst (2000) nos lembra que uma coisa é reconhecer que os genes constituem parte das condições básicas nas quais os problemas de saúde ocorrem, outra coisa é atribuir aos genes um papel central nesse processo. A re-classificação das doenças como "genéticas" tem um grupo de conseqüências importantes: isto acrescenta ao sentido social dessas doenças o encargo social que o doente tem que carregar, ou seja, o fato de as doenças genéticas serem vistas numa perspectiva determinista, reducionista e terem implicações familiares (JUENGST, 2000). Há, portanto, o indicativo de que em genética, como em outras áreas, é preciso que não se isole o problema técnico posto pelo tratamento de uma determinada doença, da atenção devida à pessoa do doente em todas as suas dimensões (JOÃO PAULO II, 1981).

Ao lado das questões éticas levantadas, muito pode ser dito a respeito do que está sendo feito para transformar o poder efetivo da genética em técnicas saudáveis e justificáveis de superação e alívio do sofrimento de todos os seres vivos. Porém, infelizmente, também temos que indicar o modo como a genética está sendo utilizada como arma de dominação que consolida e aumenta as contradições de um mundo já dividido. É este aspecto do impacto social da pesquisa genética que abordamos neste artigo.

A questão social se torna relevante, pois não podemos ignorar, como no caso do movimento 
eugênico do início do Século XX, que os conhecimentos científicos são cooptados por alguns grupos para a realização de seus objetivos, nem sempre defensáveis, e nem sempre de maneira democrática. Entendemos que a eugenia encontra seu mais radical questionamento exatamente quando a realidade social atual é trazida para a discussão. Os que cedem aos encantos da eugenia o fazem exatamente porque afirmam que estão vivendo numa sociedade individualista e de livre concorrência (CAPLAN, 2000). No entanto, cedendo ao equívoco da eugenia estão exatamente levando a ideologia do individualismo e da concorrência às situações ainda mais desumanas. Isto porque permitir uma nova "versão" humana geneticamente "melhorada" implica numa automática opressão de todos aqueles que foram excluídos de tal "melhoria" (PETERS, 1999). Alguns, um pouco exageradamente, sob nosso ponto de vista, alertam:

... Há o risco de o conhecimento gerado pelo Projeto Genoma Humano levar à criação de uma sub-casta de párias genéticos a quem seriam negados empregos, planos de seguro e talvez até o direito de ter filhos. Diante dessas possibilidades o impacto da nova genética não se restringe apenas ao foro do que poderíamos chamar de "moralidade pessoal": haverá conseqüências para a forma e a organização da sociedade mais ampla (WILKIE, 1994).

A problemática social não pode ser a grande ausente dos debates e da busca de uma postura ética frente às novas descobertas e possibilidades de intervenção das biociências sobre a vida. A HUGO (2000) publicou um relatório de um grupo de estudo em que considerou como bastante provável que a pesquisa genética que visa lucro aumentará as desigualdades entre ricos e pobres, entre nações ricas e nações pobres, e encorajará as grandes companhias de biotecnologia a partilhar uma percentagem de seus lucros, e que elas façam isso voluntariamente em harmonia com os valores e preferências das comunidades onde atuam, para que se tornem "boas cidadãs globais". Qual será a eficácia deste bom conselho?

\section{Genética e justiça}

Muitos concordam com o princípio de igualdade de oportunidade, mas há muitos desen- contros a respeito do modo como este deve ser compreendido (BUCHANAN; BROCK; DANIELS, 2000). Buchanan et al. (2000) apresentam o debate a respeito da justiça no contexto da pesquisa genética. Não há dúvida de que esse assunto não pode ser facilmente exaurido, mas não podemos deixar de afirmar que o poder da genética está diretamente vinculado às possibilidades da genética perpetuar a injustiça ou suprimi-la.

A problemática da igualdade e desigualdade social, obviamente, antecede o desenvolvimento da pesquisa genética. Kitcher (2000) reconhece que o Projeto Genoma Humano não traz nenhum novo problema ético, mas ele se torna problemático por causa da existência de "um contexto de instabilidade". O conhecimento do genoma humano não é discriminador nem injusto, mas um contexto de discriminação e injustiça pode utilizá-lo para se perpetuar.

Mehlmam; Botkin (1998) vão um pouco mais longe e apontam que a distribuição dos benefícios genéticos pode se tornar tão desequilibrada que uma sociedade democrática, como a que conhecemos, pode não ser sustentável. Esse autor está sugerindo que a base da democracia, igualdade de oportunidade e liberdade cai por terra quando uma pessoa nascer geneticamente melhorada e outra continuar nascendo como resultado da loteria genética, que ocorre no pareamento dos cromossomos. Poderia uma sociedade, que abrigasse em seu seio tamanhas diferenças, ainda ser chamada de democrática?

A pergunta, obviamente, não precisa ser remetida ao futuro. Podemos perguntar se uma sociedade onde uma pessoa tem acesso a uma ótima dieta alimentar, enquanto outra cresce desnutrida, onde uma cresce com acesso a todos os recursos educacionais e outra condenada à situação de analfabetismo, pode ser chamada de democrática? Com isso não estamos desvalorizando as implicações sociais do desenvolvimento em genética, mas estamos defendendo que tanto em genética, como em educação, política, economia, e outras áreas, a questão social precisa ser contemplada, para não vermos todo o progresso cultural da humanidade se tornar refém de poucos e ser usado como arma contra a grande maioria. É por isso que defendemos que a questão social está no centro do debate e que o imperativo ético atual, para todas as áreas, é exatamente o contexto social global. 
Assistindo ao filme GATACA, cujo nome já é uma clara referência às "letras" químicas do DNA, as pessoas são colocadas diante de uma nova forma de discriminação social: o genomismo, como a distinção entre pessoas com um genoma "melhorado" e as pessoas que nasceram sem esta melhoria genética. A possibilidade de existirem humanos geneticamente modificados ainda é remota e considerada por alguns como inviável (DULBECCO , 1997). Uma das conseqüências do PGH "será assinalar as diferenças entre os indivíduos humanos em nível genético", o que poderá "representar solo fértil para novos pretextos de discriminação" (WILKIE, 1994). A discriminação por causa da constituição genética já é um fato conhecido, basta analisar o que ocorre nas clínicas de reprodução assistida e o resultado dos testes genéticos.

Mehlmam; Botkin (1998), conscientes que a pesquisa genética pode aprofundar a desigualdade social a extremos, mesmo dentro das fronteiras dos países ricos, analisam algumas propostas de solução a partir da preocupação igualitária. Uma primeira solução igualitária seria o governo proibir todos de ter acesso às tecnologias genéticas, baseado no princípio da igualdade, ou seja, enquanto não é possível que todos tenham acesso aos benefícios da genética, então ninguém o teria, pois um serviço de saúde deve ser oferecido apenas se for oferecido a todos que precisam dele, por ser injusto tratar de alguém se não é possível tratar de todos. Não precisa ser um especialista no assunto para perceber que essa solução não seria aceita pela sociedade, e não é prudente sugerir para a genética algo que não é aplicado em outras áreas da vida humana. Não esperamos todos ter acesso à compra de carros para iniciar sua produção.

A segunda alternativa que este autor apresenta seria não banir toda a pesquisa genética, mas parte dela, em algumas áreas como as que lidam com "células germinais e melhoramento genético", tendo em vista que essas áreas serão utilizadas realmente por uma pequena parte da população mais abastada. No entanto, essa solução é vista como impossível, pois não dá para isolar algumas áreas "porque as técnicas são muito semelhantes". O próprio conhecimento do genoma, extremamente relevante para o conhecimento dos genes causadores de doenças, torna-se também instrumento para conhecimento de todo o genoma, abrindo as portas para aqueles que não querem pesquisar doenças, mas apenas escolher a cor dos olhos dos seus filhos. Como a pesquisa não pode ser evitada, então se sugere que o governo proíba a sua aplicação ao menos até o momento que todos possam ter acesso à mesma tecnologia.

Uma outra solução indicada pelo autor seria utilizar os serviços oferecidos pela genética de maneira igualitária, de modo que, na medida em que os recursos forem disponibilizados, sejam universalizados os serviços e, enquanto os recursos são limitados, deve-se utilizar a estratégia do sorteio, ou seja, todos os que precisam concorrem e serão tratados os que forem sorteados. Cresce nos ciclos de debate em bioética a reflexão sobre a distribuição dos recursos de saúde, desafio ainda maior nos países em desenvolvimento (FORTES, 2003). O que se percebe, mesmo nos países ricos, é que os benefícios disponibilizáveis pela engenharia genética dificilmente serão utilizados a partir de princípios igualitários. Basta lembrar que nos Estados Unidos, de cada quatro pessoas, uma tem dificuldade de acesso aos serviços de saúde, por falta de plano de saúde.

Alguns poderiam imaginar que os recursos genéticos seriam colocados à disposição de cada criança, mas é exatamente aí que a proposta mostra sua contradição, se a realidade social for devidamente contemplada (PETERS; RUSSEL, ANO). O fato de alguma técnica nova ser possível não significa que será disponível a cada criança. Observa-se que inúmeras técnicas bem mais simples já estão disponíveis há décadas, como as drogas, que são de conhecimento geral, e, no entanto, inúmeras pessoas no planeta continuam perecendo por não poder adquiri-las. Ainda hoje em dia, em algumas regiões da África, morrem de 40 a 70 mulheres em cada mil em decorrência da gravidez, enquanto em países ricos a média é de um em cada 10.000 (ELKINS, 2000). A Organização Mundial da Saúde tem observado que apenas 5\% dos gastos globais em pesquisa de saúde estão destinados "às necessidades dos países em desenvolvimento, os quais sofrem $93 \%$ das mortes prematuras do mundo" (O'MATHÚNA, 2000).

Talvez pudéssemos nos aproximar da questão da justiça na distribuição dos serviços disponibilizados pela genética, a partir de um ângulo realista, onde a meta da igualdade é apresentada como um desafio para cada pessoa, como também para a sociedade. Não podemos confundir igualdade social com uniformidade ou ausência 
de diversidade. Entendemos que a uniformidade social é impossível, não desejada e se ocorresse seria desumana. Acreditamos que uma pessoa não se sente violada, nem injustiçada, quando se depara com a diversidade social e cultural. A injustiça social ocorre quando as diferenças são escandalosas, quando oprimem, tolhem a liberdade das pessoas. Muitas diferenças sociais nascem da diversidade social. A diversidade por si não ofende quando se torna serviço, pelo contrário, ela pode ser libertadora, promotora de vida.

A diversidade, para ser libertadora, devese colocar a serviço, como na relação entre os profissionais das mais diferentes áreas e seus clientes ou pacientes. Quando um especialista em genética presta serviço a uma empregada doméstica, percebe-se que a diversidade está a serviço da vida. A desigualdade social, que nasce desta diversidade, não é, em si, questionada. Essa desigualdade se torna escandalosa quando a empregada doméstica não tiver acesso aos serviços do especialista em genética.

Estamos sendo realistas em aceitar uma certa desigualdade social e estamos sendo otimistas quando acreditamos que todos podem se enriquecer com a complexa diversidade social e cultural, e que esta diversidade traz, em si, alguns elementos de desigualdade. A desigualdade se redime quando se torna serviço e o serviço deixa de estar subordinado à ideologia dominante quando se torna serviço a todos. Entendemos que esta proposição, para se tornar fato, é desafiadora, porque o serviço a todos só será real se for serviço aos mais pobres, conforme defendemos num outro trabalho: "A defesa do pobre é o único caminho para que a ética possa de fato ser vista como promotora da dignidade de todos" (SANCHES, 2004).

Um pesquisador poderá fazer diferentes pesquisas, mas se ele quiser assumir uma postura eticamente igualitária, deverá optar preferencialmente por aquelas pesquisas e trabalhos que resolvam os problemas dos mais pobres, tanto as pesquisas que tenham efeito imediato, como as que pensam a sociedade a longo prazo. Não é sem motivo que Tom Wilkie (1994) questiona:

Serão os povos do Terceiro Mundo lembrados na escolha de áreas de estudo pelos cientistas do Primeiro Mundo, ou enfermidades como as cardiopatias e o diabetes de início tardio, geneticamente mais complicadas e, portanto, mais atraentes, absorverão o interesse dos pesquisadores? Elas tendem a ser doenças da riqueza, afetando, sobretudo, os mais abastados.

Se alguém falar que o problema social não traz problemas éticos para a pesquisa nas biociências, então estaria isolando estas ciências do seu contexto socioeconômico. A escandalosa desigualdade social que estamos vivendo coloca 0 grande problema ético dos tempos atuais e o faz para todos. Nenhum setor da atividade humana está isento desse questionamento. Toda vez que as biociências se colocam a serviço dos sonhos daqueles que, por serem detentores de poder econômico, querem manipular técnicas especiais para si ou para os seus se perpetuarem no poder, elas falham na sua missão mais básica e mais sublime: promover vida para todos.

Entendemos que a grande responsabilidade do ser humano e a sua maior missão é exatamente trabalhar na superação do sofrimento. Deste modo, curar doenças é um objetivo intrinsecamente ético. Todo e qualquer esforço humano na perspectiva da cura de doenças não precisa de outra justificativa ética, ele se justifica por si, desde que seja feito por métodos aceitáveis. Portanto, todo o aparato tecnocientífico da genética deve receber da sociedade uma aprovação entusiasmada, por causa das novas possibilidades de cura de doenças que isso traz consigo. É claro que essa mesma sociedade deve zelar para que novas possibilidades não se tornem novos mecanismos de opressão, ou novas maneiras de perpetuar velhas chagas da sociedade, como a desigualdade social e a discriminação de grupos humanos.

O problema é o uso que será feito destes novos conhecimentos, mas a possibilidade de cura de doenças novas e velhas realmente não pode deixar de despertar entusiasmo e recebe o merecido apoio de lideranças religiosas. Uma intervenção estritamente terapêutica, que se propõe como objetivo a cura de diversas doenças, como as que se referem a deficiências nos cromossomos, será, em princípio, considerada positiva, contando que tenda à verdadeira promoção do bem-estar pessoal do homem, sem ameaçar a integridade ou deteriorar as condições de vida (JOÃO PAULO II, 1999). 


\section{Dominação tecnocultural}

Siqueira (2005) aponta que temos vivido um tempo de "imperativo tecnológico". Mieth (2003) complementa dizendo que o poder sobre os genes se torna uma nova forma de dominação. Estamos assistindo à hegemonia de um sistema ideológico que apregoa a técnica como um elemento superior em relação aos outros componentes da complexidade cultural. Neste contexto, os projetos que demandam alta tecnologia são mais facilmente financiados pela sociedade, enquanto outros que são igualmente urgentes e talvez mais relevantes podem ser relegados a um segundo plano. As soluções que envolvem mais tecnologias são mais apreciadas do que as que não utilizam técnicas sofisticadas, mesmo que o resultado seja o mesmo.

Esta tão aclamada "cultura científica" acaba impondo às pessoas pesados fardos. Quem não se adapta, quem não se insere, quem não se submete, acaba sendo excluído do processo de promoção e de realização humana. Isto tudo aponta para o conflito entre tecnologia e cultura no contexto da diversidade cultural de diferentes países. Como a tecnologia é apregoada como um valor universal, perde-se o senso crítico e "embutido com a tecnologia, não raro, transplantam-se soluções para dilemas de vida que servem muito bem na cultura de origem, mas não se adequam à nova realidade cultural, sem falar dos modismos" (BARCHIFONTAINE, 1996).

As vozes críticas precisam ser ouvidas para que junto com a tecnologia não estejamos comprando um projeto de sociedade que não seja o nosso, e até mesmo um projeto de sociedade que contenha elementos bastante estranhos aos valores de nossa sociedade. É o que Junges (1999) quer dizer quando afirma que a

... Europa e Estados Unidos são os cultores da ideologia do progresso e originam, em seu meio, permanentes brotes de tendências eugenistas. O Projeto Genoma Humano, liderado por estes países, alijou, desde o início, os países em desenvolvimento, podendo sofrer um desvirtuamento eugenista.

Surge então o questionamento se nós somos capazes de utilizar toda esta tecnologia sem nos submetermos a um sistema ideológico domi- nante (BEIGUELMAN, 1996). E assim somos colocados diante da realidade de que os países ricos mesmo "não tendo em seus territórios os recursos biológicos necessários à bio-indústria são donos do conhecimento que possibilitam a utilização da natureza viva como fonte de perene riquezas" (OLVEIRA, 1996).

Os que detêm a tecnologia se sentem no direito de se apropriar dos recursos naturais, em qualquer país onde eles se encontram, e transformar isto em uma nova fonte de riqueza para si mesmo (WILKIE, 1994). Assim, as grandes empresas de biotecnologia "financiam expedições por todo o Hemisfério Sul, em busca de traços genéticos raros e originais, que possam ter algum valor comercial. Os interesses potenciais envolvidos são enormes. Basta que se considere o valor das novas drogas (RIFKIN, 1999). Esses "caçadores de genes", em nome da superioridade tecnológica, apropriam-se de conhecimentos acumulados há séculos por comunidades tradicionais e o que eles chamam de "descobertas" são, na verdade, pirataria do conhecimento acumulado pelos povos e culturas nativos" (RIFKIN, 1999). Essas empresas vasculham os centros de diversidade genética, servem-se livremente da generosidade de seus tesouros, para vendê-los de volta, a altos preços, sob uma forma levemente alterada e patenteada os mesmos produtos que foram livremente partilhados e comercializados entre agricultores por toda a história da humanidade (RIFKIN, 1999).

Deste modo, o desenvolvimento da genética sofre um terrível desvirtuamento ético, pois as grandes conquistas da biotécnica continuam reservadas para os ricos, prestando-se a formação de monopólios e latifúndios, onde a produção agrícola e animal é controlada por quem está de posse da tecnologia biológica (ANJOS, 1988).

\section{A problemática busca da superioridade}

A capacidade de a genética melhorar a vida humana é óbvia e é parte da mais autêntica e responsável tarefa dos seres humanos. As tecnologias genéticas reduzirão a incidência de doenças graves e providenciarão tratamento para tantas outras, e, neste sentido, elas se tornam instrumento privilegiado no compromisso daqueles que buscam eliminar o sofrimento de seus semelhantes e de outros seres vivos. 
O melhoramento genético, no entanto, também traz a dificuldade de se definir as fronteiras, pois do ponto de vista da biologia, faz sentido pensar em doença, saúde e melhoramento como um todo se encaixando num simples contínuo (BUCHANAN; BROCK; DANIELS, 2000).

Os problemas surgem quando a terapia genética é aplicada, não ao tratamento de uma doença identificável, mas para realçar características existentes, não para retificar erros da natureza, mas para aperfeiçoar sua obra (WILKIE, 1994).

Por isso gostaríamos de distinguir o melhoramento genético que visa tornar alguém mais saudável e capaz de ter melhor qualidade de vida, da eugenia, que busca a superioridade a qualquer preço, e que visa tornar alguém geneticamente "melhor", e em contrapartida descrimina os que são excluídos deste "melhoramento", como foi visto acima.

Talvez aqui valesse a pena pensar na questão de que o parâmetro básico é a aceitação da condição humana: o tratamento de uma doença deve procurar fazer alguém mais humano, mais capaz de exercer suas capacidades humanas. Isto não significa fazer alguém biologicamente melhor do que os outros, mas pelo contrário, torná-lo plenamente humano e capaz de conviver e interagir com a ampla comunidade humana. Qualquer modificação genética que pretenda tornar uma pessoa subumana ou super-humana deveria então ser entendida como extremamente problemática e antiética por si. Assim, quando se busca na genética a possibilidade de ir além da condição humana, vislumbra-se um quadro bastante sombrio para a humanidade, e o uso da genética para a confecção de humanos superiores em âmbito individual e social vai requerer nossa atenção para uma "série de paradoxos sociais" (CONDIT, 1999).

Os paradoxos sociais começam quando as pessoas especulam a respeito da possibilidade de usar as técnicas genéticas disponíveis para programar geneticamente um superbebê, uma mulher maravilha ou um super-homem, normalmente esquecendo um elemento básico da biologia: que o ambiente trabalha junto com o genótipo para moldar o fenótipo de qualquer ser vivo (KITCHER, 2000). Com isto fica patente que a eugenia não é um desvirtuamento da ciência genética, mas uma ideologia que pretende manipular a genética, para atingir seus objetivos.

Buscar a perfeição é missão humana e não há nada de errado nisso, e qualquer casal equilibrado vai sonhar com um bebê perfeito, o mais perfeito possível.

A posição mais forte, apoiando as tentativas de aperfeiçoar as crianças por meio de intervenção genética, seria que é moralmente adequado aos pais, ou outros, procurar produzir a melhor criança possível (BUCHANAN; BROCK; DANIELS, 2000).

O problema, no entanto, é outro, é transformar o sonho legítimo de perfeição numa busca paradoxal de superioridade em relação aos outros. Querer um bebê perfeito é querer um bebê plenamente humano, plenamente participante da natureza e da condição humana. Sonhar com um superbebê, no sentido eugênico, é sonhar com um ser geneticamente superior aos outros humanos, que não partilha com os outros a mesma natureza e a mesma condição. Por essas razões isto é um paradoxo, é querer um humano que não seja exatamente humano.

É paradoxo também porque os pais esquecem de que o ser humano não é só genética e que as qualidades físicas que são mais valorizadas pela sociedade variam de época para época, por causa da dinâmica cultural. Se fosse possível programar os filhos, muitos pais, provavelmente, procurariam as qualidades que estivessem em moda em sua época, ou aquelas que eles próprios julgassem importantes. Contudo, vinte anos depois, os filhos poderiam deparar-se com uma realidade social em que suas qualidades não teriam mais valor algum e, por outro lado, carecendo das necessárias (DULBECO, 1997). Enfim, nossos esforços podem errar e a tentativa de beneficiar pode resultar em fazê-los pior ainda (BUCHANAN; BROCK; DANIELS, 2000).

Se um casal deseja escolher para seu bebê uma cor diferente daquela que eles lhe transmitiriam naturalmente, pode estar se equivocando em vários aspectos, deixando claro a não aceitação de si próprio, se submetendo a modismos culturais que podem ser passageiros, correndo o risco de expor o seu futuro filho ou filha a situações ridículas na sociedade. É um sinal de saúde mental, cultural e espiritual, que as pessoas, quaisquer que 
sejam suas origens étnicas, queiram ter filhos ou filhas parecidos ao máximo com elas mesmas, bebês perfeitos, plenamente identificados com a realidade étnica social e cultural dos próprios pais.

Portanto, a nova eugenia traz estes novos conflitos, ligados a uma atitude perfeccionista em relação aos filhos (CONDIT, 1999). E, se frente à eugenia clássica havia o perigo de uma ação governamental, hoje está se despontando os riscos de um excessivo individualismo. Se as pessoas são livres para seguirem seus caprichos individuais, então crianças poderão ser produzidas de modo exótico que pode não ser bom para elas mesmas como indivíduos, nem para a sociedade onde viverão (CONDIT, 1999). Aqui cabe o alerta:

...É importante que a tentativa de produzir a melhor criança possível seja entendida como fazer a vida da criança melhor para a criança e a partir do ponto de vista de seu bem particular, não melhor a partir do ponto de vista de outros, tais como o bem dos pais ou da sociedade (BUCHANAN, BROCK, DANIELS, 2000).

\section{A força do mercado}

A discussão acima sobre a busca de uma distribuição justa dos benefícios da pesquisa genética nos reconduziu à questão social e à necessidade de afirmar que a ética exigiria a prioridade dos mais necessitados. No entanto, a questão que está mais presente no debate não é exatamente 0 que é mais ético, mas sim o que dá mais lucro. Se a pesquisa genética se subordinar às leis do mercado capitalista, a prioridade deixa de ser o social, e além da tirania da tecnologia passamos também à tirania do mercado.

Autores recentes têm chamado a atenção para o fato de que nas discussões cada vez mais freqüentes sobre as escolhas bioéticas, que se desenvolvem nos encontros filosóficos e científicos, nos parlamentos, nas revistas especializadas e nos meios de comunicação, o mercado é quase sempre esquecido e é o grande ausente (BERLINGUER, GARRAFA, 1996). E se ele estiver ausente, talvez estejamos acobertando os verdadeiros objetivos da pesquisa, e o clima de feroz competição, que aponta para o fato de na pesquisa não se tratar de um simples desejo de saber, mas de uma corrida à descoberta, nas esperanças de "aparecer", de ser consagrado vedete da comunicação de massa, e na expectativa de receber o prêmio Nobel (DURAND, 1995).

Nos últimos anos surgiram as grandes companhias de biotecnologia e a questão dos interesses comerciais da pesquisa genética ficou exposta, e todas elas passaram a promover pesquisa para produzir e vender produtos para fins comerciais. Isto recoloca o problema ético no caso das doenças genéticas: "o sistema do mercado não é perfeito e suas deficiências tendem a trabalhar contra os interesses dos doentes" (WILKIE, 1994).

É necessário desenvolver e aguçar a crítica a respeito da pesquisa nestas áreas, mas não é possível, honestamente falando, admitir que o desenvolvimento esperado possa ocorrer sem a pesquisa. Por isso, é necessário assumir uma postura positiva em princípio, aberta para a pesquisa, pois o reconhecimento do valor da experimentação parece-nos a melhor atitude inicial para projetar um discernimento ético sobre esta realidade (VIDAL, 1981). Mas devemos sempre lembrar que nenhuma pesquisa ou aplicação de pesquisa relativa ao genoma humano, em especial nos campos da biologia, genética e medicina, deve prevalecer sobre o respeito aos direitos humanos, às liberdades fundamentais e à dignidade humana dos indivíduos ou, quando for o caso, de grupos de pessoas (UNESCO, 1998).

O fato é que o mercado influencia na pesquisa e que a pesquisa se tornou uma espécie de empreendimento público (DURAND, 1995). Mais de $60 \%$ dos estudos de terapia genética estão diretamente financiados por indústrias de biotecnologia, antecipando um futuro lucrativo (NELKIN, 2000). Esta tendência tem sido denunciada por líderes religiosos como João Paulo II (1981):

Certos cientistas, privados de qualquer referimento ético, correm o risco de não manterem, ao centro de seu interesse, a pessoa e a globalidade da sua vida. Mas, alguns deles, cientes das potencialidades contidas no progresso tecnológico, parecem ceder à lógica do mercado e ainda à tentação dum poder demiurgo sobre a natureza e o próprio ser humano.

Diante desta lógica do mercado, realmente a perspectiva ética desaparece, o ser humano torna-se mercadoria e propriedade. Por isso, cabe cada vez mais o esforço da sociedade de incentivar a 
pesquisa e promover as empresas que se dedicam à pesquisa de medicamentos, mas dentro de perspectivas éticas aceitáveis. Também as Companhias devem assumir o lugar de servidoras da sociedade, pois seu grande objetivo não pode inverter esta lógica e se colocar como aquelas que podem se servir indiscriminadamente da sociedade. Às grandes Companhias deve ser dito que os fins não justificam os meios, que é eticamente inaceitável produzir medicamentos possuindo e manipulando indiscriminadamente material humano vivo. Impor padrões éticos é um direito da humanidade para preservar sua integridade, como um direito de legítima defesa. Há cerca de dez anos, o Papa João Paulo II, num Encontro sobre Ciência e Fé na Áustria, observou que a toda técnica deve corresponder uma ética, e a toda ciência deve corresponder uma consciência (MACIEL, 2002).

É neste processo, que vai da pesquisa ao mercado, que surge a problemática do patenteamento de produtos biotecnológicos. Esse assunto é complexo e precisa ser estudado com propriedade, num trabalho à parte, mas dado à sua relevância e proximidade com os temas estudados neste artigo gostaríamos de introduzir o debate.

Patente é o registro que se faz de determinada idéia, novidade ou descoberta. A problemática do patenteamento dos produtos genéticos surgiu ao longo do PGH, quando em 1991 foi anunciado que os NIH (Institutos Nacionais de Saúde dos EUA) estavam tentando patentear as seqüências de DNA descobertas por seus pesquisadores (WILKIE, 1994). James Watson opôs-se à idéia, pois percebia que ela impossibilitaria o livre fluxo de informações científicas, tornando mais difícil a colaboração internacional e impedindo o progresso. Levada ao extremo, essa atitude poderia significar que cada país teria de seqüenciar por si próprio todo o genoma humano, em segredo, torcendo para que as partes que houvesse identificado já não tivessem sido patenteadas por outros.

Esta tentativa dos NIH, de patenteamento, provocou grande reação internacional. Os franceses consideravam que os genes humanos simplesmente não podiam ser protegidos por qualquer patente. Os britânicos defendiam a proibição de patentear as seqüências genéticas sem nenhuma utilidade conhecida, mas aceitavam o patenteamento das seqüências com função conhecida.

Em julho de 2002, o Conselho Nuffield de Bioética - Reino Unido publicou um relatório solicitando restrições à apropriação intelectual de seqüências genéticas, dizendo que as patentes de DNA têm sido concedidas com tanta generosidade e cobrindo uma gama tão ampla de aplicações que ameaçam atrapalhar a pesquisa. Questiona ainda se o mero isolamento de um gene preenche o requisito de inventividade necessário para uma patente nos dias de hoje, quando a bioinformática simplificou a tarefa de isolar uma seqüência perdida no meio do genoma (ANGELO, 2002).

O que se coloca é que nem os riscos associados à manipulação genética da complexa vida animal e particularmente da vida humana ainda são plenamente conhecidos, e no entanto, o sistema de patenteamento dos Estados Unidos continua a alimentar as perspectivas das pesquisas nas companhias privadas, numa lei que permite patentear qualquer coisa debaixo do sol feito pelo ser humano (SHERRY, 1997).

O grande debate na área não é contra 0 direito de patenteamento, mas sobre o que é patenteável. O conflito se apresenta ao redor de dois pontos: a) Aquilo que faz parte do ser humano pode ser objeto de patentes?b) Pode-se patentear, além de invenções, também a descoberta daquilo que já existe na natureza? (BERUNGUER; GARRAFA, 1996). Oliveira (1996) tem sua posição bem definida: "O conceito legal e universal de patentes tem como critérios: a novidade, a invenção e o interesse industrial. Imitar a natureza não é invenção! Nas manipulações genéticas não há invenção, tão somente novidade, e o interesse industrial depende muito do que se trata e em geral é uma incógnita".

Essas questões nos colocam no foco do debate, na busca de que tipo de informação genética seria patenteável. Nos Estados Unidos, onde a pesquisa genética avançou primeiro, o PTO propõe uma política que levante algumas barreiras para a aplicação de patentes. $\mathrm{O}$ avanço, para alguns cientistas, ainda não é suficiente. Para usufruir as regalias do PGH, as Companhias investiram milhões no estudo dos genes, nos quais podem se basear novas drogas e diagnósticos. Fizeram isso pressupondo que elas possuirão o direito de explorar o conhecimento genético.

A preocupação toda está ao redor da questão do patenteamento de material humano vivo. Sherry (1997) aponta que, sob o presente estado da lei de patente nos Estados Unidos, processos e produtos relacionados com células germinais hu- 
manas poderiam ser protegidos por patentes, que a pesquisa poderia produzir um embrião humano geneticamente alterado, um determinado embrião novo e útil poderia ser patenteado, clonado e vendido, e que a terapia genética patenteada poderia ser a base para produzir humanos transgênicos ou embriões transgênicos. Este autor indica que, de fato, a presente lei de patente pode criar e incentivar a pesquisa direta para alterar a linhagem germinal humana e desenvolver material humano geneticamente modificado. De acordo com a lei, um ser humano geneticamente modificado não seria considerado humano. A lei de patente já considerou que um rato geneticamente modificado é distinto de um rato natural não alterado geneticamente. A mesma distinção pode ser suficiente para abrir a porta para possibilitar patente de vida humana geneticamente alterada (SHERRY, 1997). Assim as patentes vão se ampliando a partir de conquistas prévias. Um caso famoso nos Estados Unidos, como o Chakrabarty, que concedeu a patente a uma bactéria geneticamente modificada, abriu espaço para que em 1988 também um 'oncomouse', que foi criado geneticamente por cientistas da Universidade de Harvard, pudesse ser patenteado (AGIUS, 1998).

Segundo Agius (1998), o debate moral sobre patentes está levantando duas questões fundamentais a respeito de seus efeitos sobre os povos menos desenvolvidos tecnicamente e sobre as futuras gerações:

a) A conveniência de conceder direitos de propriedade sobre novas formas de vida está sendo seriamente questionada por causa de seus efeitos em longo prazo para os futuros membros da espécie humana. Os novos tipos de 'produtos' criados pela biotecnologia e as ameaças potenciais a gerações futuras desafiam as classificações tradicionais da lei de direito de patente. b) Os sistemas de patenteamento atuais adotados nas regiões industrializadas do mundo estão aumentando a distância entre os países desenvolvidos e em desenvolvimento. Leis de patentes estão facilitando várias companhias multinacionais a controlar as indústrias de processamento de produtos farmacêuticos, de substâncias químicas, agrícolas e de alimento. Estas empresas estão protegendo seus próprios interesses adquirindo controle de monopólio (por patentes) sobre recursos genéticos e tecnologia.
Estão sendo ameaçados as chances do Terceiro Mundo ter acesso à informação científica e os direitos de patentear a tecnologia.

Agius (1998), enfim, deixa-nos uma pergunta inquietante: "Quais são os possíveis efeitos da lei dos sistemas de patente praticada atualmente no hemisfério norte, sobre os países em desenvolvimento?'.

No Brasil, o registro de patentes é feito no INPI (Instituto Nacional de Propriedade Industrial), a fim de preservar cópias de reproduções ilegais. O pedido para obtenção de uma patente deve satisfazer os seguintes critérios: novidade, nãoobviedade (inventividade), utilidade (aplicação industrial). A Lei da Propriedade Industrial 9279/ 96 proíbe patentear "o todo ou a parte de seres vivos naturais e materiais biológicos encontrados na natureza, ou ainda que dela isolados" (ANGELO, 2002).

No $1^{\text {o }}$ Congresso Brasileiro de Legislação Ambiental, Ética e Biodireito, ocorrido em Maio de 2002, na cidade de Ribeirão Preto - SP, foi abordado o tema das patentes genéticas e das tentativas de apropriação do patrimônio biológico pelas empresas de biotecnologia. Renato de Paula Magri afirmou que "juridicamente a lei de patentes que existe no Brasil não permite isto, já que ela diz que nenhum ser vivo, em todo ou em parte, pode ser patenteado. E isso inclui seus genes". Edgar Dutra Zanotto, compara a situação ao patenteamento do conjunto dos elementos químicos: imagine patentear a tabela periódica ou o lítio. Isso não existe (LOPES, 2002).

Apesar das vozes críticas, este tema do patenteamento de material biológico precisa ser mais bem estudado, e estar mais presente em debates que envolvam toda a sociedade. Isto porque as pressões econômicas são muitas, e se a sociedade não estiver atenta, o campo do material biológico poderá se tornar mais uma seara loteada entre poucos.

\section{Conclusão}

Pelo presente trabalho, reconhecemos a grande importância das pesquisas genéticas para toda a humanidade, ao mesmo tempo em que nos questionamos sobre o real e verdadeiro uso inteligente do conhecimento alcançado. 
Almeja-se um acesso ético e digno aos avanços da tecnologia, respeitando-se as desigualdades, onde as diferentes classes sociais tenham oportunidades de serem beneficiadas, promovendo uma minimização das injustiças que tanto enfrentamos atualmente.

Vale ressaltar que cada ser humano contribui fundamentalmente para o desfecho das situações que envolvem os avanços da genética, onde as pessoas podem e devem solicitar as respostas às suas perguntas, para que opinem com discernimento sobre o que é eticamente aceitável ou não, pensando em uma promoção de vida para todos. A responsabilidade não nos permite esconder atrás de instituições ou condicionamentos externos. Cada um, na esfera de sua ação, precisa assumir compromisso com o uso adequado das novas tecnologias, de modo que elas sejam colocadas, de fato, na perspectiva da construção de uma sociedade cada vez menos injusta. A responsabilidade é, portanto, na ética, a articulação entre duas realidades, uma subjetiva e outra objetiva. É forjada por essa fusão entre o sujeito e a ação (SIQUEIRA, 2005).

\section{Referências}

AGIUS, E. Patenting life: our responsibilities to present and future generations. In: AGIUS, Emmanuel; BUSUTTIL, Salvino, (Eds.). Germ-line intervention and our responsabilities to future generations. Dordrecht: Kluwer Academic, 1998. p. $68-83$

ANDERSON, V. E. Resisting reductionism by restoring the context. In: ; KILNER, J. F.; PENTZ, R. D.; YOUNG, F. E. (Eds.). Genetic ethics: do the ends justify the genes?Grand Rapids: Wm.B.Eerdmans, 1997. p. 84-94.

ÂNGELO, Cláudio. Folha de São Paulo, São Paulo, 01 out. 2002. Caderno de Ciência, A11.

ANJOS, M. F. Bioética a partir do terceiro mundo, In:____ $\quad$ ANJOS, M. F. (Coord.). Temas latinoamericanos de ética. Aparecida: Santuánio, 1988. p. 211-232.

BARCHIFONTAINE, C. P. Bioética e Reprodução Medicamente Assistida. In: ; PESSINI, L.; BARCHIFONTAINE, C. P. (Orgs.). Fundamentos da Bioética. São Paulo, SP: Paulus, 1996.
BEIGUELMAN, B. Genética e ética. In: PESSINI, L; BARCHIFONTAINE, C. P. (Org.s.). Fundamentos da bioética. São Paulo, SP: Paulus, 1996. p.108-123.

BERLINGUER, G.; GARRAFA, V. 0 mercado Humano: estudo bioético da compra e venda de partes do corpo. Brasília: Universidade de Brasília, 1996.

BEURTON, P. J.; FALK, R.; RHEINBERGER, H. J. (Eds.). The concept o the gene in development and evolution: historical and epistemological perspectives. Cambridge: Cambridge University, 2000 .

BUCHANAN, A.; BROCK, D. W.; DANIELS, N. et al. From chance to choice: genetics and justice. Cambridge: Cambridge University, 2000.

CAPLAN, A. L Whatis moraly wrong with eugenics? In: $\quad$; SLOAN, P. R. (Eds.). Controlling our destinies: historical, ethical, and theological perspectives on the Human Genome Project. Notre Dame: University of Notre Dame Press, 2000.

CONDIT, C. M. The meanings of the gene: public debates abouthuman heredity. Madison, Wisconsin: 1999.

COOK-DEEGAN, $R$. The gene wars: science, politics and the human genome. New York: W. W. Norton, 1994.

CRANO R, C. F. Are gene us? The social consequences of the new genetics. New Brunswick, N. J.: Rutgers University, 1994.

DAVIES, K. Cracking the genome: inside the race to unlock human DNA. New York: The Free, 2001.

DEAVEN, L. L. Mapping and sequencing the human genome. In: _ CRANOR, C. F. Are gene us?The social consequences of the new genetics. New Brunswick, N. J.: Rutgers University, 1994. p.13-30.

PENTZ, R. D.; YOUNG, F. E. (Eds). Genetic Ethics: do the ends justify the genes? Grand Rapids: Wm.B.Eerdmans, 1997. p. 25-39.

DULBECCO, R. Os Genes e o Nosso Futuro: 0 desafio do Projeto Genoma. São Paulo, SP: Best Seller, 1997.

DURAND, G. A bioética: natureza, princípios, objetivos. São Paulo,SP: Paulus, 1995. 
DYCK, A. J. Eugenics in historical and ethical perspective. In:___ ;ILNER, J. F.; PENTZ, R. D.; YOUNG, F. E. (Ed.s.). Genetic ethics: do the ends justify the genes? Grand Rapids: Wm. B. Eerdmans P. Co. / Paternoster, 1997.

ELKINS, T. E. A Medical Educator's Perspective. In:__ ; KILNER, F. J.; CUNNINGHAM, P. C.; HAGER, D. W. (Ed.s). The reproduction revolution: a christian appraisal of sexuality, reproductive technologies, and the family. Grand Rapids: Cambridge, UK: William B. Eerdmans, 2000. p.15-17.

FORTES, P. A. C. Como priorizar recursos escassos em países em desenvolvimento. In: ; GARRAFA, V.; PESSINI, L Bioética: poder e injustiça. São Paulo, SP: Loyola, 2003. p. 103-114.

HEFNER, P. J. A criação. In: ; BRAATEN, C. E.; JENSON, R. W. (Ed.s.). Dogmática cristã. São Leopoldo: Sinodal, 1990. v. 1.

HUMAN GENOME ORGANIZATION (HUGO). Genetic benefit sharing. Science, v. 6, n. 260, p. 49, oct. 2000.

INTERNATIONALHUMANGENOME SEQUENCING CONSORTIUM. Initial sequencing and analysis of the human genome. Nature. v. 409, p. 860-914, feb. 2001.

JOÃO PAULO II. Alocução aos membros da Associação Médica Mundial (29 de outubro de 1983). In:____ ;IDAL, M. Moral de atitudes: ética da pessoa. 3. ed. Aparecida: Santuário,. 1981. v. 2. p. 425-430.

JOÃO PAULO II. Fides et ratio. São Paulo, SP: Paulinas, 1999.

JONAS, H. The imperative of responsability. In: ; Search of an ethics for technological age. Chicago: University of Chicago, 1984.

JONES, S. Darwin's ghost: the origin of species updated. New York: Random House, 2000.

JUENGST, E. T. Concepts of disease after the human genome project. In: ; WEAR, S. et al. (Ed.s.). Ethical issues in health care on the frontiers of the twenty-firstcentury. Dordrecht: Kluwer Academic, 2000. p.127-154.

JUNGES, J. R. Bioética: perspectivas e desafios. São Leopoldo: UNISINOS, 1999.
KAPLAN, J. M. The limits and lies of human genetic research: dangers for social policy. New York: Routledge, 2000.

KAY, L E. Who wrote the book of life? a history of the genetic code. Stanford, California: Stanford University, 2000.

KELVES, D. J. In the name of eugenics: genetics and the uses of human heredity. New York: Alfred A. Knopf, 1985.

KELVES, D. J. Out Of Eugenics: The historical politics of the human genome. In: ; KELVES, D. J.; HOOD, L (Ed.s.) The Code Of Codes: scientific and social issues in the human genome project. Cambridge, MA: Harvard University, 1992. p 3-36.

KITCHER, P. Utopian eugenics and social inequality. In:___ ; SLOAN, P. R. (Ed.s.). Controlling our destinies: historical, ethical, and theological perspectives on the Human Genome Project. Notre Dame: University of Notre Dame, 2000. p. 229-262.

KOLATA, G. Nightmare of the dream of a new era in genetics (1993). In: ; SHANNON, T. A. (Ed.s.). Genetic engineering: a documentary history. Westport, Connecticut: Greenwood, 1999. p.205-209.

LEWONTIN, R. The triple helix: gene, organism, and environment. Cambridge: Harvard University, 2000.

LOPES, R. J. Folha de São Paulo, São Paulo, 11 maio, 2002. CadernoCiência.

MACIEL, M., Folha de São Paulo, São Paulo,12 ago.2002. Opinião.

MARKS, J. Human biodiversity: genes, race and history. New York: Aldine de Gruyter, 1995.

MEHLMAM, M. J.; BOTKIN, R. J. Access to the genome: the challenge to equality. Washington, $\mathrm{D}$. C.: Georgetown University, 1998.

MIETH, D. Aditadura dos genes. Rio de Janeiro,RJ: Vozes, 2003.

NATIONAL RESEARCH COUNCIL Mapping and sequencing the human genome. Washington, D. C.: National Academy, 1988.

NELKIN, D. From promises of progress to portents of peril: public responses to genetic engineering. 
In: ; WEAR, S. et al., (Ed.s.). Ethical issues in health care on the frontiers of the twentyfirst century. Dordrecht: Kluwer Academic, 2000. p.155-170.

O'MATHÚNA, D. P. The Goals of Medicine: The case of viagra. In: ; KILNER, F. J.; CUNNINGHAM, P. C.; HAGER, D. W. (Ed.s.). The Reproduction Revolution: a Christian appraisal of Sexuality, reproductive technologies, and the family. Grand Rapids: William B. Eerdmans, 2000. p. 46-59.

OLIVEIRA, F. Engenharia genética: o sétimo dia da criação.In: ;PESSINI, L; BARCHIFONTAINE, C. P. (Org.s.). Fundamentos da bioética. São Paulo, SP: Paulus, 1996.

PENA, S. D. J.; AZEVEDO, E. S. O Projeto Genoma Humano e a medicina preventiva: avanços técnicos e dilemas éticos. In: ; COSTA, S. I. F.; OSELKA, G.; GARRAFA, V. Iniciação à bioética. Brasília: Conselho Federal de Medicina, 1998. p.139156.

PESSINI, L; BARCHIFONTAINE, C. P. (Org.s.). Fundamentos da bioética. São Paulo, SP: Paulus, 1996.

PETERS, T. F. Genome Project Forces New Look at Ethics, Law (1993). In: ; SHANNON, T. A. (Ed.). Genetic Engineering: a documentary history. Westport, Connecticut: Greenwood, 1999. p. 130136.

PETERS, T. F.; RUSSEL, R. J. The human genome project: what questions does it raise for theology and ethics? (1992). In: ; SHANNON, T. A. (Ed). Genetic engineering: a documentary history. Westport, Connecticut/ London: Greenwood, 1999. p.117-121.
RIFKIN, J. $O$ século da biotecnologia: a valorização dos genes e a reconstrução do mundo. São Paulo, SP: Makron, 1999.

SANCHES, M. A. Bioética ciência e transcendência. São Paulo, SP: Loyola, 2004.

SHERRY, S. The incentive of patents. In: KILNER, J. F.; PENTZ, R. D.; YOUNG, F. E. (Ed.s.). Genetic ethics: do the ends justify the genes? Grand Rapids: Wm. B. Eerdmans, 1997. p.113-123.

SIQUEIRA, J. E. O imperativo tecnológico e as dimensões da responsabilidade. In: SIQUEIRA, J. E. (Org). Ética, ciência e responsabilidade. São Paulo, SP: Loyola, 2005.

SLOAN, P. R. (ed). Controlling our destinies: historical, philosophical, ethical and theological perspectives on the human genome project. Notre Dame: University of Notre Dame, 2000.

UNESCO. 29ạ Assembléia Geral - 1997. Declaração universal do genoma e dos direito humanos: artigo 1o. 0 mundo da saúde. São Paulo, v.22, n. 22, jan./ fev. 1998.

VENTER, C. et al. The sequence of the genome. Science. v. 291, p. 1304, feb. 2001.

VIDAL, M. Moral de atitudes, ética da pessoa. 3. ed. Aparecida: Santuário, 1981. v. 2.

WILKIE, T. Projeto genoma humano: um conhecimento perigoso. Rio de Janeiro,RJ: Jorge Zahar, 1994.

Recebido em: 07/03/2005

Aprovado em: 28/06/2005 